\title{
Assessment of Human Factors Causes of Occupational Risk in the Chemical Industry Using the Analytic Network Process (ANP) Method
}

\author{
Rurry Patradhiani $^{1 *}$, Maimana ${ }^{2}$ \\ 1,2 Department of Industrial Engineering, Faculty of Engineering, Universitas Muhammadiyah \\ Palembang, South of Sumatra Indonesia,30263 \\ *Corresponding Author: \\ Email: patradh24@gmail.com
}

\begin{abstract}
.
The development of the industry in Indonesia is inseparable from the analysis of the production process and identification of the risk of causing work accidents. In every production process in the chemical industry there are various risks that cause occupational accidents, the biggest cause of accidents comes from human factors. It required a priority assessment of workplace accidents influence on the human factor as the cause of the rising incidence of labor in the production process in the chemical industry with the method of Analytic Network Process (ANP), of the assessment results using ANP method can be determined to set a risk management strategy causes of accidents. ANP method is done by determining goals, criteria, and sub criteria. In this case the criteria are the production process and the sub criteria are human factors that cause the risk of work accidents. Furthermore, the value of influence between criteria is determined, between criteria and sub criteria and between sub-criteria. The results obtained are the highest limiting values for criteria, namely the final product process and sub-criteria, namely human factors not using PPE. Strategies that can be taken to control risk is by giving reward and punishment, providing HSE training, as well as the management is partially responsible for HSE
\end{abstract}

Keywords: Human Factors, Risk Management, Analytic Network Process (ANP)

\section{INTRODUCTION}

The growth of a country can not be separated from the development of industry in the country, one of the fastest growing industries today is the chemical-based manufacturing industry. Products in the chemical industry are widely used in daily life, such as soap, pharmaceuticals, cement, fertilizers, gasoline, disinfectants. As well as the benefits that can be given from chemical products but there are also high hazard effects arising from chemicals and the production process [1]. One of the dangerous effects arising from the production process include explosions, fires and even poisoning. Hazards in the production process include the processing of chemicals and storage of chemicals that can cause major hazards so that in the prevention of effectiveness is needed in hazard identification as a first step in minimizing the risk of work accidents in the production process in chemical industry [2]. Accidents of work can occur because of two things: the humans in this regard workers as the cause of the accident as well as the responsible management of the pen cegahan 
accidents. Based on the Center for Occupational Health in 2010 as many as $80-85 \%$ causes of occupational accidents in the industry due to negligence or mistakes caused by humans.

The high number of work accidents that are influenced by human factors due to workers' awareness of OSH is still low [3]. This can be seen from the noncompliance of workers using helmets, masks, anti-slip shoes, and other personal protective equipment (PPE) when working as well as other $\mathrm{K} 3$ rules violations. Unsafe Behavior is negligence of workers who do not use PPE when working, do not work according to procedures. While unsafe conditions arise because of the conditions of the work environment and work facilities that do not support, for example, an old machine, rusty, ambient temperature that is not according to standards. Unsafe behavior factors are strongly influenced by personal factors [4]. The factors that influence the occurrence of these accidents can be corrected by providing training and knowledge to workers so that workers are expected to be able to identify hazards, analyze hazards, make appropriate decisions to avoid hazards by behaving safely at work [5].There is a lot of research on the identification of risks that cause occupational accidents, but there are not many studies that explain the priority assessment of human factors as causes of work accidents. The relationship between humans and machines in a system as one of the causes of the emergence of work accidents [6]. In this study, which has been conducted related to the identification and analysis model of occupational accident risk in the chemical industry that focuses on human factors [7].

Identification and analysis of risks that generated modeling of the influence of behavior on the emergence of the risk of accidents in the work environment the chemical industry. Furthermore, for this study the models obtained related to the influence of behavior were assessed using the Analytic Network Process (ANP) method to determine the magnitude of the influence of risk factors on the emergence of occupational accident risks. Where the results are used as a basis for determining the risk control strategy in the chemical process to reduce work accidents. The problem in this study is how to model the priority of the relationship between risk and human factors as causes of risk. The priority assessment of the relationship between risk and human factors as causes of risk aims to obtain a risk control strategy with an employee behavior approach The Analytic Network Process (ANP) is a development of the Analytic Hierarchy Process (AHP). Where the ANP structure is a network, the ANP structure considers the dependency and feedback relationship while the AHP does not [8]. Another advantage of ANP is that it gives better results in making analytic comparative models that are appropriate and precisely made. The foregoing reasons the ANP method is often used in decision making in qualitative research involving various interrelated factors that have more objective comparisons, more accurate predictions, and more stable and perfect results [9]. ANP uses a simple process but complex problems in various fields can be solved [10]. 


\section{METHODS}

In a previous study[7] stated that there was an influence of the causes of occupational accident risks to the risk events described in the causal effects diagram. The identified causes of risk focus more on unsafe worker behavior. Where the unsafe behavior of workers is the cause of the emergence of risk of work accidents in almost all risk event variables. The behavior of workers who do not use PPE is often found in the work area, causing risk events to emerge. An assessment of the effect of the causes of occupational accident risks on risk events can be done using the Analytic Network Process (ANP) method.

In the ANP method can determine the weighting of criteria and sub-criteria of existing relationships and look for the relationship of influence between criteria and sub-criteria. For it is determined beforehand that $m$ en so the criteria and subcriteria. The criteria in this study are risk events based on the stages of the process and sub-criteria are the causes of risk events due to worker behavior. Determination of subcriteria is based on the results of the causal effet diagram model where unsafe worker behavior is the biggest cause of the emergence of work accident risk. After determining the criteria and sub-criteria next describe the network network model (ANP)

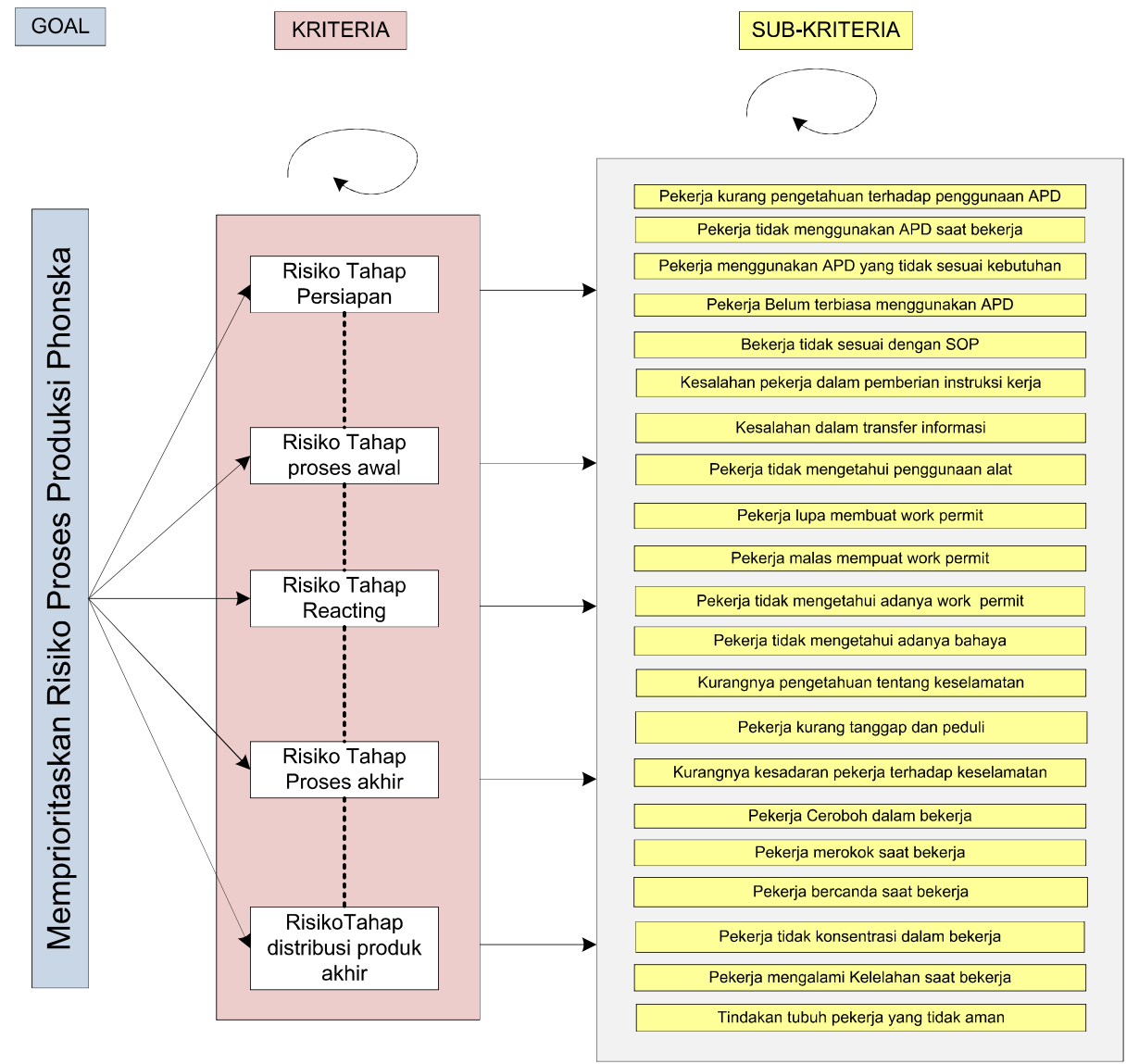

Fig 1. ANP Model

http://ijstm.inarah.co.id 
Data at the weighting stage is obtained from questionnaires filled out by experts, where the questionnaire is divided into three parts, namely the assessment of influence between criteria, assessment of influence between sub criteria, and assessment of influence between criteria and sub criteria. Respondents who were involved in filling out questionnaires were from experts who were directly involved in the field of K3 studies and company production processes so that they could give a good assessment of this research.

\subsection{Relationship between effect of Criteria}

In this section an evaluation is conducted between criteria, where the criteria referred to are risks at each stage of the production process. The effect evaluation between criteria uses a scale of values from 0 to 9 , where when the respondent gives a value of 9 it means that the risk event will greatly affect other risk events, and if the value is 0 then it means that the two risk events do not affect each other. Following below is an assessment of the relationship between the criteria displayed in the table

Table 1. Assessment of the Effect of Relationship Between Criteria

\begin{tabular}{lccccc}
\hline \multicolumn{1}{c}{ Kriteria } & C1 & C2 & C3 & C4 & C5 \\
\hline Risiko Tahap Persiapan (C1) & 0 & 9 & 9 & 9 & 1 \\
Risiko Tahap Proses Awal (C2) & 1 & 0 & 7 & 5 & 3 \\
Risiko Tahap Reacting (C3) & 1 & 5 & 0 & 9 & 3 \\
Risiko Tahap Proses Akhir (C4) & 1 & 3 & 5 & 0 & 7 \\
Risiko Tahap Distribusi Produk Akhir (C5) & 1 & 1 & 1 & 7 & 0 \\
\hline
\end{tabular}

\subsection{Relationship Between effect of Sub Criteria}

At this stage an assessment of influence between sub-criteria is carried out, in which the assessment is carried out to determine the extent of the influence of a human factor as a cause of accident risk on the appearance of accident risk in the production process. In the assessment of influence between sub-criteria using pairwise comparisons ranging from 1 to 9 , where a value of 1 means that human factors as a cause of an accident slightly affect other factors and a value of 9 means that human factors as a cause of an accident greatly affect other factors .

\subsection{Relationships between Criteria and Sub Criteria}

At this stage the respondents assessed the effect of inter criteria and sub criteria, where human factors cause occupational accident risk as a sub criteria and the emergence of risk at the process stage as a criterion. Assessments are given using a scale of 1 to 9 based on pairwise comparisons. A value of 1 means that showing human factors as the cause of an accident slightly affects the emergence of risk at the process stage, while a value of 9 indicates that human factors as a cause of an accident greatly affect the emergence of risk at each stage of the process.

\subsection{ANP Model Weighting}

Weighting between criteria, criteria with sub criteria, between sub criteria can be done with the help of Superdecision 2.0 software. In processing data using Superdecision 2.0 produces a supermatrix that has not been weighted so for each criterion it needs to be multiplied to get a weighted supermatrix. To get the weight of 
each criterion, the weighted supermatrix value has been carried out to produce a stable weight. The weight value is said to be stable if the dominance between elements has been distributed throughout the matrix. Matrix that has a stable weight is also called a limiting matrix. Matrix limiting needs to be normalized so that the weighting of the criteria and sub-criteria is known how much influence. Priority weights can be obtained if the consistency value is less than 0,1 . Furthermore, from the influence relationship between the criteria, between the criteria and sub-criteria, and between the sub-criteria, the next step is to do a pairwise comparison of the assessments obtained from the questionnaire. There are pairwise comparisons for each cluster. Pairwise comparisons for relationships between criteria are shown in the table below.

Table 2. Pairwise comparisons for relationships between criteria

\begin{tabular}{ccccc}
\hline Inconsistency & $\mathrm{C} 2$ & $\mathrm{C} 3$ & $\mathrm{C} 4$ & $\mathrm{C} 5$ \\
\hline $\mathrm{C} 1$ & 8 & 8 & 8 & 1 \\
$\mathrm{C} 2$ & & 2 & 2 & 2 \\
$\mathrm{C} 2$ & & & 4 & 2 \\
$\mathrm{C} 4$ & & & & 1 \\
\hline
\end{tabular}

Table 3. Pairwise comparisons for the relationship between criteria and sub-criteria

\begin{tabular}{ccccc} 
Inconsistency & $\mathrm{C} 2$ & $\mathrm{C} 3$ & $\mathrm{C} 4$ & $\mathrm{C} 5$ \\
\hline $\mathrm{C} 1$ & 2 & 2 & 2 & 1 \\
$\mathrm{C} 2$ & & 2 & 2 & 4 \\
$\mathrm{C} 2$ & & & 1 & 2 \\
$\mathrm{C} 4$ & & & & 2
\end{tabular}

Table 4. Pairwise comparisons for relationships between sub-criteria

\begin{tabular}{|c|c|c|c|c|c|c|c|c|c|c|c|c|c|c|c|c|c|c|c|c|c|}
\hline & SC1 & $\mathrm{SC} 2$ & $\mathrm{SC} 3$ & $\mathrm{SC4}$ & $\mathrm{SC5}$ & $\mathrm{sc6}$ & SC7 & SC8 & SC9 & SC10 & SC11 & $\mathrm{SC} 12$ & SC13 & SC14 & SC15 & SC16 & SC17 & SC18 & SC19 & SC20 & SC21 \\
\hline $\mathrm{SC} 1$ & & 2 & 2 & 1 & 4 & 2 & 4 & 4 & 1 & 1 & 1 & 2 & 2 & 2 & 2 & 2 & 1 & \begin{tabular}{|l|} 
\\
\end{tabular} & 1 & 2 & 1 \\
\hline $\mathrm{SC2}$ & & & 2 & 2 & 1 & 2 & 2 & 2 & 1 & 1 & 1 & 2 & 2 & 1 & 2 & 2 & 1 & 4 & 4 & 4 & 2 \\
\hline $\mathrm{SC} 3$ & & & & 2 & 1 & 4 & 2 & 2 & 1 & 1 & 1 & 4 & 2 & 2 & 1 & 1 & 1 & 2 & 4 & 2 & 1 \\
\hline \begin{tabular}{|l}
$\mathrm{SC} 4$ \\
\end{tabular} & & & & & 2 & 1 & 2 & 6 & 2 & 2 & 4 & 2 & 1 & 1 & 2 & 2 & 2 & 2 & 2 & 2 & 1 \\
\hline SC5 & & & & & & 4 & 4 & 1 & 2 & 1 & 4 & 1 & 1 & 2 & 1 & 2 & 1 & 2 & 2 & 4 & 2 \\
\hline $\mathrm{SC6}$ & & & & & & & 2 & 1 & 4 & 1 & 4 & 1 & 1 & 4 & 2 & 2 & 1 & 4 & 1 & 6 & 1 \\
\hline$\widehat{S C 7}$ & & & & & & & & 1 & 4 & 1 & 4 & 1 & 1 & 2 & 2 & 4 & 4 & 6 & 2 & 6 & 2 \\
\hline \begin{tabular}{|l}
$\mathrm{SC} 8$ \\
\end{tabular} & & & & & & & & & 4 & 4 & 2 & 2 & 2 & 4 & 2 & 2 & 4 & 2 & 1 & 2 & 1 \\
\hline SC9 & & & & & & & & & & 4 & 2 & 2 & 4 & 4 & 4 & 1 & 1 & 2 & 2 & 4 & 1 \\
\hline SC10 & & & & & & & & & & & 1 & 2 & 4 & 6 & 4 & 1 & 1 & 2 & 4 & 1 & 1 \\
\hline SC11 & & & & & & & & & & & & 4 & 2 & 2 & 4 & 2 & 1 & 1 & 2 & 2 & 1 \\
\hline $\mathrm{SC} 12$ & & & & & & & & & & & & & 2 & 2 & 2 & 4 & 1 & 4 & 2 & 2 & 1 \\
\hline SC13 & & & & & & & & & & & & & & 1 & 1 & 4 & 2 & 1 & 2 & 1 & 1 \\
\hline \begin{tabular}{|l|}
$\mathrm{SC} 14$ \\
\end{tabular} & & & & & & & & & & & & & & & 1 & 1 & 4 & 1 & 2 & 4 & 1 \\
\hline SC15 & & & & & & & & & & & & & & & & 2 & 2 & 2 & 2 & 4 & 1 \\
\hline SC16 & & & & & & & & & & & & & & & & & 2 & 6 & 4 & 6 & 1 \\
\hline SC17 & & & & & & & & & & & & & & & & & & 1 & 1 & 6 & 1 \\
\hline $\mathrm{SC} 18$ & & & & & & & & & & & & & & & & & & & 4 & 4 & 1 \\
\hline SC19 & & & & & & & & & & & & & & & & & & & & 4 & 2 \\
\hline $\mathrm{SC} 20$ & & & & & & & & & & & & & & & & & & & & & 1 \\
\hline SC21 & & & & & & & & & & & & & & & & & & & & & \\
\hline
\end{tabular}

The next stage is to obtain priority weight scores from the supermatrix calculation of each criterion and sub-criteria shown in the following table 5 
Table 5. Priority Value Criteria

\begin{tabular}{ccc}
\hline Name & Normalized By Cluster & Limiting \\
\hline C1 & 0.11850 & 0.059250 \\
C2 & 0.17579 & 0.087893 \\
C3 & 0.20189 & 0.100944 \\
C4 & 0.29368 & 0.146841 \\
C5 & 0.21014 & 0.105071 \\
\hline \multicolumn{3}{c}{ Table 6. Priority Value Sub-Criteria } \\
\hline Name & Normalized By Cluster & Limiting \\
\hline SC1 & 0.07234 & 0.036170 \\
SC2 & 0.07526 & 0.037630 \\
SC3 & 0.06046 & 0.030230 \\
SC4 & 0.05570 & 0.027848 \\
SC5 & 0.05693 & 0.028467 \\
SC6 & 0.04876 & 0.024379 \\
SC7 & 0.05870 & 0.029348 \\
SC8 & 0.03322 & 0.016608 \\
SC9 & 0.02939 & 0.014696 \\
SC10 & 0.03236 & 0.016179 \\
SC11 & 0.03225 & 0.016126 \\
SC12 & 0.04851 & 0.024256 \\
SC13 & 0.03597 & 0.017986 \\
SC14 & 0.03545 & 0.017727 \\
SC15 & 0.03566 & 0.017832 \\
SC16 & 0.06220 & 0.031102 \\
SC17 & 0.03993 & 0.019963 \\
SC18 & 0.06841 & 0.034203 \\
SC19 & 0.06456 & 0.032279 \\
SC20 & 0.01706 & 0.008528 \\
SC21 & 0.03689 & 0.018443 \\
\hline
\end{tabular}

\section{RESULT AND DISCUSSION}

Weighting criteria and sub-criteria, in this case the criteria are risks at each stage of the production process and sub-criteria are human factors that cause the emergence of risk at the production process stage, the aim is to find out the highest risk in the production process that can cause work accidents and know the factors humans who most cause the risk of work accidents, so that from the weighting results can be minimized the risk of the production process and carried out control of human factors as a cause of occupational risk The weighting of risk at each stage of the production process is derived from the value of the link given by the respondent. This relationship is in the form of the effect of a criterion on other criteria. In the questionnaire three models of linkages are given, the first linkage between criteria, the second linkage between criteria and sub-criteria, the third linkage between sub-criteria.

The value of the influence of the relationship between criterion one $(\mathrm{C} 1)$ against criterion two (C2) is not the same as the value of the effect of criterion two (C2) on criterion one (C1). This also applies to the relationship between the sub - 
criteria and the criteria with the sub-criteria.Data processing has been done with software, including manual data to calculate averages with Excel to the use of Superdecision. Before looking for priority values of criteria and sub-criteria first make an influence relationship model with Superdecision. From the relationship model, weighting for each criterion and sub-criterion is carried out until the value and priority of software processing are known.The pairwise comparison values obtained in the previous calculation are entered into Superdecision to get the matrix value between the criteria and sub-criteria. The matrix value is then processed by Superdecision to obtain priority values from each criterion and sub-criteria. Priority values generated from each of the criteria and sub-criteria that have been ranked can be seen in the following table 7

Table 7. Ranking of priority criteria and sub-criteria

\begin{tabular}{ccc}
\hline Kriteria & Nilai & Rangking \\
\hline C4 & 0.29368 & 1 \\
C5 & 0.21014 & 2 \\
C3 & 0.20189 & 3 \\
C2 & 0.17579 & 4 \\
C1 & 0.11850 & 5 \\
\hline Subkriteria & Nilai & Rangking \\
\hline SC2 & 0.07526 & 1 \\
SC1 & 0.07234 & 2 \\
SC18 & 0.06841 & 3 \\
SC19 & 0.06456 & 4 \\
SC16 & 0.06220 & 5 \\
SC3 & 0.06046 & 6 \\
SC7 & 0.05870 & 7 \\
SC5 & 0.05693 & 8 \\
SC4 & 0.05570 & 9 \\
SC6 & 0.04876 & 10 \\
SC12 & 0.04851 & 11 \\
SC17 & 0.03993 & 12 \\
SC21 & 0.03689 & 13 \\
SC13 & 0.03597 & 14 \\
SC15 & 0.03566 & 15 \\
SC14 & 0.03545 & 16 \\
SC8 & 0.03322 & 17 \\
SC10 & 0.03236 & 18 \\
SC11 & 0.03225 & 19 \\
SC9 & 0.02939 & 20 \\
SC20 & 0.01706 & 21 \\
\hline
\end{tabular}

From the table above, for the criteria cluster, it can be seen that the risk that has a high competitiveness value will greatly affect the emergence of work accidents, that is, the risk at the final process stage, followed by the risk at the final product distribution stage, reacting stage risk, initial process stage risk, and risk those that have little effect on the appearance of work accidents are risks at the preparatory stage. Weighting criteria and sub-criteria using the ANP method basically gives a value 
to each criterion and sub-criteria based on the value given by respondents in the questionnaire, where the value given is the value of the relationship between criteria, between sub-criteria, and between criteria and sub-criteria .

The risk of the final stage of the process has a major influence on the emergence of work accidents in the production process compared to the risks at the fabric stage, this is because it is influenced by the causes and impacts of the risks. One of the causes that gives the biggest impact on the emergence of work accidents is the lack of knowledge of workers on the use of PPE so that workers do not use PPE at work. While the impact of the risk of the final stage of the process is the disruption of workers' health due to injuries received and can even result in death. Because the value of the causes and effects of this final stage of risk is high, making this risk a first priority for control. For the percentage of priority criteria can be seen in Figure 2 below .

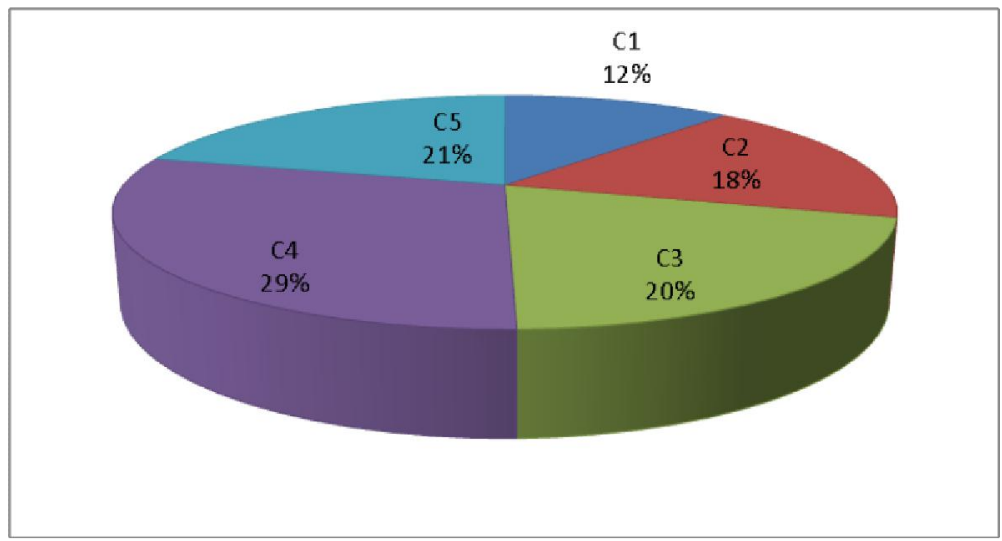

Fig 2. Percentage value of criteria

In the sub-criteria cluster, the final result of the priority value shows the greatest influence of the sub-criteria as the cause of work accidents in the production process. From the priority value obtained in data processing using Superdecision, the biggest cause of work accidents arises because workers who do not use PPE while working, are followed by a lack of knowledge of workers about the use of PPE, workers 'joking behavior at work, workers who are not concentrated at work, workers' attitudes careless when working, workers who use PPE that is not according to their needs, workers who make mistakes in information transfer, workers who work not according to SOP, attitude of workers who are not accustomed to using PPE, mistakes of workers in giving work instructions, workers who are not aware of any danger, workers who smoke while working, unsafe workers' body actions, lack of workers' knowledge of safety, workers' lack of awareness of safety, workers who are less responsive and caring, workers who do not know the use of tools, workers who are lazy to make work permit, workers who are not aware of a work permit, workers who forget to make a work permit, and factors that have little effect as a cause of an accident because workers who experience fatigue at work. 
Workers who do not use PPE have the highest priority value compared to other sub-criteria causing work accidents, this is because the majority of occupational accident risks are caused by workers who do not use PPE when working. Workers who work in places containing danger are required to use PPE to protect themselves from hazards, in addition to using PPE workers can also minimize the impact caused by these hazards. Therefore, workers who do not use PPE are very vulnerable to the risk of workplace accidents. Phonska fertilizer production area itself contains a lot of risks of work accidents both from chemicals and production process activities so that the behavior of workers who do not use PPE is the biggest cause of risk events. The percentage of priority values generated for the sub-criteria cluster can be seen in Figure 3 below.

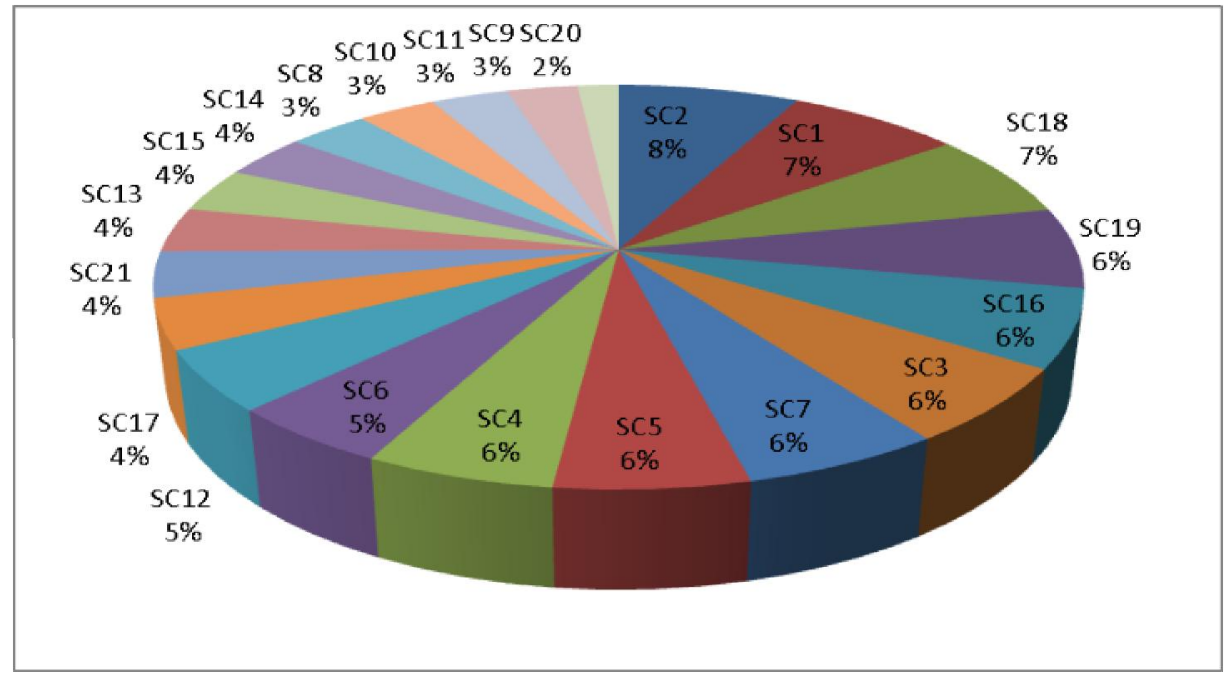

Fig 3. Percentage value of sub-criteria priority

\section{Risk Management Efforts}

In an effort to handle risk, the steps that can be taken are risk control. In controlling risk, the aim is to control the causes and impacts caused by accident risks in the production process. The existence of risk control is more able to improve the discipline of workers against work safety rules. One of the efforts to control risk in increasing workers' discipline to OSH rules is the provision of punishment that can provide a deterrent effect for workers when they violate them, while providing rewards for workers who have obeyed the OH\&S rules as a form of company appreciation for their workers. Other efforts that can be carried out in controlling risk are conducting safety training with the aim of providing knowledge on OHS. Basically, employee discipline is closely related to the knowledge possessed by workers, with safety training it is expected to be able to change the behavior of workers who are not safe to be safe behavior to achieve organizational goals. Management supervision of K3 rules can also be done as an effort to control risk in the production process. Every Occupational Health and Safety regulation that applies in the organization aims to 
create a safe, comfortable and healthy work environment, so that it is necessary to supervise management of the Health and Safety rules in an effort to minimize the risk events in the production process.

\section{CONCLUSION}

In this study it can be concluded that the ANP method is able to prioritize risks and causes of risk so that from the priority value a risk-causing control strategy can be developed that focuses on worker behavior. From the ANP method of data processing using Superdecision 2.0, the greatest risk value is obtained, namely the risk at the final process stage while the human factor as the biggest risk of emergence is caused by the attitude of workers who do not use PPE. Risk control strategies that can be carried out to minimize the emergence of occupational accident risks in the production process are by giving rewards and punishments to workers who adhere to or violate OSH regulations in the company, conduct OSH training regularly and on target as an effort to increase workers' knowledge of $\mathrm{OSH}$, and parties management always supervises the $\mathrm{K} 3$ regulations in force in the organization in order to realize organizational goals.

\section{REFERENCES}

[1] C. Huang, R. H., Yang, C., Kao, "Assessment Model For Equipment Risk Management: Petrochemical Industry Cases”," Saf. Sci., vol. Vol. 50, pp. 1056-1066, 2012.

[2] M. Bouloiz, H., Garbolino, E., Tkiouat, "Contribution of a systemic modeling approach applied to support risk analysis of a storage unit of chemical products in Morocco," Loss Prev. Process Ind., vol. Vol. 23, pp. 312-322., 2010.

[3] Anny Maryani, "Pemodelan Kecelakaan Kerja Konstruksi Yang Komprehensif Untuk Mengendalikan Biaya K3, Tesis Master, Institut Teknologi Sepuluh Nopember, Surabaya," 2012.

[4] N. L. Hanum, "Implementasi Bahavior Based Safety Pada Sistem Manajemen Keselamatan Kerja Guna Meningkatkan Safe Behavior Pekerja, Tugas Akhir Sarjana, Institut Teknologi Sepuluh Nopember, Surabaya."

[5] Dwi Iryaning, "Mitigasi Risiko Berbasis Sistem Treceability Pada Rantai Pasok Makanan, Tesis Master, Institut Teknologi Sepuluh Nopember, Surabaya.," 2012.

[6] C. " Marhavilas, P.K., Koulouriotis, D.E., Mitrakas, "On the Development of a New Hybrid Risk Assessment Process Using Occupational Accidents' Data: Application on the Greek Public Electric Power Provider"," J. Loss Prev. Process Ind., vol. Vol. 24, p. hal. 671-687., 2011.

[7] R. Patradhiani, "Model Pengembangan Risiko Kecelakaan Kerja Dengan Pendekatan Perilaku Manusia Menggunakan Metode Causal Effect Diagram," 2013.

[8] D. Iryaning, "Multi Kriteria Terhadap Penilaian Penyebab Kejadian RIsiko Kecelakaan Kerja Pada Proyek Konstruksi Dengan Metode Analytic Network Process,” J@ti Undip J. Tek. Ind. Univ. Diponegoro, Semarang, vol. Vol 13, no. No. 1 Januari 2018, 2018.

[9] Badri, A., Nadeau, S., Gbodossou, A., "Proposal of A Risk-Factor-Based Analytical 
Approach for Integrating Occupational Health and Safety Into Project Risk Evaluation"," Accid. Anal. Prvention., 2011.

[10] Mardiantony, T., "Penerapan Analisis Input Output dan ANP dalam penentuan prioritas pengembangan di Sektor industri jawa timur, Tugas Akhir Sarjana, Institut Teknologi Sepuluh Nopember, Surabaya," 2012. 